\title{
Publieke pastorale leiers 1: Roeping, werwing, keuring, opleiding, ordening
}

\author{
Malan Nel \\ (University of Pretoria)
}

\section{ABSTRACT}

\section{Public Pastoral leaders 1: Calling, recruiting, screening, training and ordination}

In ecclecial circles it is a commonplace to say that the profession of the pastor is under pressure. Pastors know that and congregations know that. Knowing it in itself does not change much. However change starts with coming to understanding. In this sense change is in itself a hermeneutical function. This article is the first of two in which I will explore a way to change the way local churches should assist in the discernment of a call by a member to become officially involved in public ministry within a congregation and, if it exists, a denomination. In this article the background of this research, the corporate nature of 'calling', and ministerial perspectives on calling, recruitment and reviewing will be explored. The second article will explore the implications for theological education as it relates to the teleological core of theological education and recruitment, reviewing (screening), and training respectively.

\section{1 'N WOORD VOORAF}

\subsection{Wat het my tot hierdie navorsing gebring}

Sedert 1970 hou my bediening op ' $n$ besondere wyse verband met die plaaslike predikant. Tot en met 1988 was dit hoofsaaklik in verband met predikante in die Ned Geref Kerk. Sedert 1988 en veral sedert 1993 staan my bediening direk in verband met predikante en pastore in ekumeniese verband. Ek het geen idee met hoeveel kerke se predikante en pastore ek oor die afgelope 11 jaar in verbinding was nie, maar minstens, op ' $n$ gereelde basis, met 11 van die bekendste denominasies in die land. In die kursusse van die Sentrum vir Kontekstuele Bediening is daar dikwels 10-15 kursusgangers per kursus en vanuit 8 en meer denominasies in dieselfde klas.

Ek is ook bevoorreg om sedert 1980 aktief by die opleiding van predikante in die Ned Geref Kerk (en sedert 1999 ook by studente uit ander kerke in die Fakulteit Teologie) betrokke te wees. Voorts bring my aktiewe betrokkenheid by sinodale werk my 
gereeld in aanraking met predikante en gesprekke oor hulle opleiding. In hierdie verband kon ek as lid van die Algemene Kommissie vir Teologiese Opleiding van die Ned Geref Kerk meewerk aan ' $\mathrm{n}$ verslag oor die noodsaak en verpligte (ook afdwingbare) voortgesette teologiese opleiding vir predikante in hierdie denominasie waarvan ek deel is. Toe ek self ' $n$ jong predikant was, het kerkleiers (waarskynlik soms ook met verborge politieke agendas) dikwels gesê dat teologiese opleiding die bron is waaruit die kerk drink. Daar moet die water skoon wees, anders word dit troebel in gemeentes. Ek het later eers besef dat ' $n$ bepaalde politieke sisteem ook hierin beskerm is. Die stelling is egter op sigself waar: die opleiding 'bepaal' in meer as een opsig die 'water' wat in gemeentes gedrink word.

Gedurende my kontak en individuele- en groep gesprekke met honderde predikante oor bogenoemde jare het my begrip vir hulle uitdagings, vrae en probleme gegroei. My betrokkenheid oor agt jaar by die Fasiliteringskommissie van die Sinode van Noord-Transvaal (vir 6 jaar as voorsitter) het waarskynlik ook 'n rol gespeel in my besluit om meer formeel aan die probleem van werwing, keuring, opleiding en voortgesette opleiding aandag te gee. Ek is oortuig dat die beslissende rede vir hierdie navorsing gesoek moet word in my groeiende belangstelling (oor meer as twintig jaar) in die vakgebied Gemeentebou en die rol van predikante en pastore in die opbou van missionêre gemeentes. Ek is meer oortuig as ooit dat die kerk en teologiese opleiding meer kan doen in belang van predikant en gemeente om te verseker dat groter erns gemaak word met wie, waarvoor en hoe opgelei word.

In die wete dat iemand my verkeerd kan hoor, moet ek dit wel as nog ' $n$ rede vir my navorsing noem: die hartseer van en skade in gemeentes, wat ook deur predikante veroorsaak word, tref my oor jare heen diep. Dit kan nie net publieke sondes wees wat predikante uit gemeentes kry nie. Die proses beskerm predikante, maar nie altyd die gemeente nie. Soms 'ontdek' iemand eers in die tweede of selfs derde gemeente dat hierdie beroep nie vir haar of hom is nie. Dan is die skade gewoonlik klaar gedoen - so dikwels onomkeerbaar. Die plaaslike gemeente is te dikwels nog die laboratorium waar met bediening eksperimenteer word.

In 2002 het ek ' $n$ eerste tree in die rigting van meer formele akademiese besinning in die rigting van die bespreking van die probleem gegee (Nel 2002b:151-167). 


\subsection{Die probleem}

Die probleem van kerke rondom die wêreld is dat nie alleen die beroep van die predikant onder druk is nie, maar ook die persoon self. My navorsing oor die belang en invloed van persoonlikheid in en op prediking was reeds deel van my waarneming van ' $n$ groter wordende probleem: die predikant, sy werwing, keuring en opleiding (Nel 2001).

Wat is dan die probleem? Voorlopig sou dit soos volg gestel kan word:

1 Persone wat reeds in die bediening is, is onder druk. Groot getalle en hoë persentasies (sommige stel dit op 33\%) van almal het al oorweeg om die beroep te verlaat of het reeds. 'Een kwart van de gereformeerde gemeentepredikanten gaat na verloop van tijd ander werk doen' (Heitink 2001:227).

2 Is almal wat aanmeld vir opleiding en van ' $\mathrm{n}$ roeping tot die bediening getuig werklik geroep? Hoe onderskei die 'geroepene' en die kerk die geldigheid van roeping?

3 Waarvoor meld iemand aan wat predikant wil word? Hoe vaag het dit geword? Watter opleiding is nodig om te 'kwalifiseer' en watter voortgesette opleiding laat iemand sy 'kwalifikasie' behou? Is die opleiding relevant vir wat 'verwag' word?

4 Is daar ' $n$ sisteem wat in " $n$ meerdere mate die kandidaat en die gemeente kan beskerm? Aan die een kant beskerm teen ' $n$ beroep en werksruimte wat onoorsigtelik geword het en aan die ander kant teen 'werknemers' wat miskien nooit op hierdie manier en plek moes deelneem aan die roeping van Christene in kerk en samelewing nie.

\subsection{Doel van die navorsing}

Met inagneming van die sensitiewe en komplekse aard van die saak onder bespreking, is dit my oortuiging dat daar " $n$ beter weg moet wees om gemeente en predikant te help. Die saak waarom dit gaan raak die eer van God en die koms van die Koninkryk. Dit raak God se wil. Die doel is onomwonde:

Om ' $\mathrm{n}$ weg te vind vir gemeentes en die kerk in verband (en inrigtings waar predikante vir " $n$ bepaalde kerk opgelei word) om op ' $n$ verantwoordelike wyse en met die nodige sensitiwiteit

1 geskikte kandidate vir die bediening te werf; 
2 kandidate wat die roeping tot die bediening ervaar, te help om hierdie roeping voor en tydens opleiding te onderskei (keuring);

3 hierdie kandidate te begelei en op te lei;

4 kandidate wat kwalifiseer te legitimeer en orden tot algemene en besondere bedieninge;

5 geordende predikante gestruktureerd in te skakel by voortgesette teologiese opleiding (lewenslange leer) en beroeptoetsing ten einde ordening te behou en in die bediening goed toegerus, kompetent en vaardig te bly.

In my eerste artikel oor die onderwerp het ek dit gestel dat die voorlopige navorsing ernstige vrae na vore bring: is daar opleidingsinrigtings wat gewillig is om met kerke in gesprek te tree ten einde die gaping tussen professionele opleiding en wat genoem word 'church-based-training' te oorbrug en is daar kerke met die moed om werwing, toetsing en voortgesette opleiding vir die behoud van bevoegdheid vir die bediening meer ernstig te neem? (Nel 2002:164).

\subsection{Aanpak}

My aanpak van die navorsing behels ' $n$ literatuur studie oor die probleem in ander kerke en in teologiese nadenke. Ek vermeng hiermee my eie insigte soos wat dit oor jare heen ontwikkel het. Ten einde die artikels en verslag toeganklik te maak vir ' $n$ breër leserskring, het ek gekies vir voetnotas eerder as die 'suiwer' Harvard verwysingsisteem. Ek sou die studie dus beskrywend, met ' $n$ duidelike strategiese doel, noem.

Ek het gekies om nie teologiese argumente wat in die meeste kerke uitgemaak is, weer te beredeneer nie. So ' $n$ saak is byvoorbeeld die noodsaak van teologiese opleiding vir die bediening. Daar is in die navorsing, soos hier gerapporteer, wel argumente vir byvoorbeeld teologiese opleiding, maar die doel is nie om 'n saak daarvoor uit te maak nie. Dieselfde geld 'n saak soos die ampte as sodanig. Ek het ook doelbewus gekies om nie in te gaan op ' $n$ saak soos detail kurrikulering nie. Sou die navorsing daartoe lei dat kerke besluit om met hul eie of ekumeniese inrigtings, waar hulle kandidate opgelei word, in gesprek te tree, sal kurrikulering beslis deel van die gesprek word. 


\subsection{Indeling}

Artikel 1:

1 ' $\mathrm{n}$ Woord vooraf

$2 \quad$ Inleiding

3 Perspektiewe op roeping

4 Bedieningsperspektiewe op roeping, werwing, keuring, opleiding en ordening

Artikel 2

1 Perspektiewe op Teologiese Opleiding

1.1 Teleologiese kern in teologiese opleiding

1.2 Werwing, keuring en teologiese opleiding

1.2.1 Die Gemeente in werwing en keuring

1.2.2 Die Kerkverband: werwing, keuring en opleiding

1.2.3 Die Kerkverband: keuring, opleiding en toelating

6 Samevattend

\section{INLEIDING}

\section{1 'n Beroep en persoon onder druk}

Dit is ' $\mathrm{n}$ gemeenplaas om te sê dat die beroep van die predikant onder druk is ${ }^{1}$. Predikante weet dit en gemeentes ervaar dit. Die samelewing is al minder daarvan bewus, want die publieke rol van die predikant is voorlopig uitgespeel. "Maatschappelijk gezien wordt het beroep meer en meer onzichtbaar" (Heitink 2001:255). Indien so ' $\mathrm{n}$ rol nodig is, en ek is oortuig dat dit is, sal dit herwin moet word.

Met verwysing na die druk waaronder die beroep is stel James Kalthoff, President van die Missouri District van die Lutherse KerkMissouri Synod, dit so: "At the risk of understatement, I honestly believe that being a pastor in our day in America is one of the most challenging, yet undervalued vocations among most people in our country ${ }^{2}$. Reeds in die jaar 1600 skryf Perkins dat goeie bedienaars

1 Vgl Böhmer \& Spangenberg (2001); Van Nijen (1993:43-56); Roux (1(1):52-53); Barna (1998); Gibbs (2000); Brouwer (1995); Heitink (2001:13-22,177 ev.).

2 Kalthoff 1998:123. Vgl ook sy aanhaling van Stowell 1994:18: "add to this the growing cynicism toward our kind from our self-inflicted wounds 
min en skaars is (Perkins 1996:99). Stephen Carter verwys na die beroep en sy eise in ' $n$ hoofstuk onder die opskrif: 'recognizing a stressful occupation' (Carter 1986:11-23). Sonder om vir een oomblik te veralgemeen of te verkleineer deel ek ' $n$ waarneming met Barry wat as moderator van die Lutherse Sinode in Missouri in 1997 in ' $n$ omsendbrief skryf: "We have a bundle of disheartened, downtrodden pastors out there. They crave... encouragement" (Barry 1997). En tog, ten spyte van die afneem van die 'prestige' van predikant wees en kompleksiteit van die taak om meer as een generasie te bedien "the expectation of congregational members for the person holding the Office of Public Ministry have never been higher... As a result of such expectations, pastors feel they are being pulled in so many directions that they feel stressed out and inadequate for what was thought of as the 'noble task'. Not measuring up to expectations, many of them fall under harsh criticism by their members. Then comes discouragement" (Kalthoff 1998:125).

'n Feit rakende die krisis rondom die 'beroepsgroep', maar wat minder dikwels in literatuur figureer is die kwaliteit van persone in die beroep. ' $n$ Studie wat dit wel direk aanhaal, verskyn in 2001 by die Alban Instituut. In hierdie navorsing word verwys na die bevinding van ' $\mathrm{n}$ groep 'presbytery leaders' in die Presbyterian Church in the U.S.A. waarin nie net besorgdheid oor ' $n$ te kort in personeel bespreek word nie, maar 'it is also a decline in the quality of those whom the church is calling to the office of minister of the Word and Sacrament'. James Wind (en ander) verwys verder daarna dat die gesprek oor die kompetensie van leierskap wissel tussen ' $n$ ondersoek na die kwaliteit van die persoon saam met sy of haar voorbereiding vir die rol van leierskap en die gebrek aan duidelikheid of redelikheid van die rol van leier op sigself. Daar is groot besorgdheid oor die feit dat 'new clergy simply do not have the talents, skills, and knowledge they need to become effective leaders. This deficit was at times attributed to certain lacks in the talent pool; at other times it was laid at the door of the seminaries' (Wind \& Rendle 2001). 'n Direkte aanhaling uit die verslag van die 'presbytery leaders' is hier van pas. In ' $n$ hele poel van kandidate vir die bediening vind hulle: "Certain attitudes and behaviors of some

of public failure and you begin to understand why we are so marginalized in terms of influence". 
recent seminary graduates which undermined or impeded pastoral ministry; inability to analyze and understand congregations as systems, poor interpersonal skills, poor leadership skills, lack of maturity, failure to keep ethical norms and boundaries, and failure to take responsibility for self, including personal health". Hulle konkludeer dat dit tyd is vir die denominasie om die standaard te verhoog en die 'brightest and best' te werf'. (In alle billikheid moet gemeld word dat Wind \& Rendle ook bevind dat ten midde van en miskien selfs ten spyte van die krisis binne die beroepsgroep daar ook opvallende tekens van die ontkieming van nuwe lewe, groei en vitaliteit in die Amerikaanse kerklike lewe is (Wind \& Rendle 2001:1). In ' $n$ opvolg bespreking van hierdie verslag in 2003 reflekteer Burkat, Nasionale Direkteur vir 'Missions' in twee van die Sinodes van die Evangelical Lutheran Church, op veral die ' $k$ waliteit van pastorale leierskap'. Om haar woorde te gebruik: "I would add a few more concerns: The ability to think theologically, and to cast a vision of a hopeful future, along with the desire to help unify the body of believers rather than escalate anxieties, are personal traits in short supply. How shocking to note the Missouri Synod study conducted by Alan and Cheryl Klaas that as many of $20 \%$ of the clergy are in advanced stages of burnout and perhaps another $20 \%$ are well on their way" ${ }^{4}$. Wind in sy eie refleksie, twee jaar later, skryf dat hulle na alle terugvoer op die verslag, oortuig is van die ontwikkelende nuwe lewe aan die een kant, maar aan die ander kant "Alban remain convinced that leadership is the pivotal issue for the well being of U.S. congregations and denominations" (Wind 2003:33).

In een van die nuutste studies binne vier denominasies bevind Hoge \& Wenger dat die eerste twee redes waarom pastors die bediening verlaat het is: "I felt drained by the demands on me" en "I felt lonely or isolated". Die mees genoemde oorsaak van spanning wat tot uittrede gelei het, was 'pastoral leadership style'. Die ondersoek bevind verder dat agter hierdie 'probleem' lê die botsing tussen "don't-change-anything"' en jong leiers wat nuut dink sowel as leiers wat skuif en wat in hulle vorige gemeente "long gratifying pastorates" gehad het. "The most important reason for leaving the local church ministry was stress and conflict, often coupled with

3 The Presbyterian Outlook September 25, 2000:10-11.

4 Burkat (2003:31). Vgl. ook Simmons (2003:29-30). 
feelings of lack of denominational support'...' [T] he main factors pushing local church ministers away are organizational and interpersonal ${ }^{5}$ ".

\subsection{Selfverstaan}

Waarskynlik deels as gevolg van die druk op die beroep is die selfverstaan van die predikant ook problematies en onder druk. Veranderinge in die samelewing speel ook hierin ' $n$ rol. In sy verwysing na die belang van lewensbeskouing merk Heitink op dat, in die huidige samelewing, onderskeid gemaak moet word tussen lewensbeskouing met of sonder religie, religie met of sonder godsdiens, Christelike godsdiens of nie, Christelike godsdiens met of sonder die kerk en laastens kerklik met of sonder kerklike betrokkenheid (meelewing) (Heitink 2001:248). Die Umwelt van die predikant het pluralisties en onoorsigtelik geword. Die vraag is dan 'wie is ek' binne hierdie wêreld wat my en my beroep skynbaar nie meer nodig het nie. Die predikant word al meer vir al minder en tegelyk al minder vir al meer. Dit is veranderinge in die samelewing wat ons tot nadenke verplig (Woodruff 1993:1-33).

\subsection{Professionalisering}

' $\mathrm{n}$ Ander saak wat inleidend tot hierdie navorsing vermeld word, is die 'debat' rondom die professionalisering van die beroep. Baie van die outeurs wat in hierdie navorsing aangehaal word, bespreek dit sommige meer positief as ander. Ek verklaar hier my gebruik van die term. In sy baie goeie boek oor opleiding vir die bediening beskryf Schner drie betekenisse van die term professioneel (Schner 1993:2). Eerstens is daar die verband met wat ons 'beroep' sou kon noem; tweedens is daar die onderskeiding tussen professioneel en amateur en derdens die algemene gebruik waar "professional means 'qualified' or 'competent' or even simply 'well-done'". Ek gaan die begrip in laasgenoemde betekenis gebruik. Dit is ook wat ek met die 'sekularisering' van die beroep in my vorige artikel bedoel het: ons moet die beroep op ' $\mathrm{n}$ vlak kry waar van die predikant gekwalifiseerde kompetensie verwag word, soos van enige ander Christen wat in sy of haar beroep gekwalifiseerd en kompetent moet wees (Nel 2002b:153). In die betekenis van die woorde van ons Meester is ek oortuig daarvan dat ook predikante beroepsgewys behoort te kwalifiseer vir die "mooi so goeie en getroue dienskneg"

$5 \quad$ Hoge \& Wenger $(2003: 8,18)$. Vgl ook Wind \& Rendle (2001:4-6). 
(Matt 25:21). In die woorde van Schner moet ons herontdek dat om predikant te wees beteken "to be professional, practical, and devoted" (Schner 1993:xiii). Schner bespreek die "professional model' in die verband waarbinne Jackson Carroll dit verduidelik en in ' $n$ bepaalde sin 'verdedig' (Carroll 1985:7-48). Carroll vat die kritiek teen die model soos volg saam:

i) dit sit die gedagte voort dat ' $n$ buitengewone (aparte) soort vaardigheid en opleiding nodig is;

ii) dit veroorsaak probleme vir kerke wat dit nie kan bekostig nie;

iii) dit skep ' $n$ afhanklike lidmate korps;

iv) dit fokus op funksionele kompetensie eerder as op teologiese en sakramentele dimensies van die bediening;

v) dit ignoreer die 'roepingskarakter' van die bediening (Carroll 1985:9-10).

Schner merk op dat hierdie 'besware' nie noodwendig díe van die (sy) Rooms-Katolieke tradisie is nie. Vir hom is die krag van die model die klem op 'kompetensie'. Die swakheid is in die algemeen die afhanklikheid van die normatiwiteit van 'tegniese rasionaliteit' (Carroll 1985:17) en die sosiale vergestalting van die beoefening van hierdie rasionaliteit. Juis dit werk dikwels teen die kollaboratiewe en die roepingskarakter van die Christelike bediening. Volgens hom is die kolloboratiewe en die roepingskarakter juis twee sterk ekklesiologiese en geestelike werklikhede wat ons tot die modifisering van die model verplig (Schner 1993:22). Ek is oortuig van die geldigheid van Schner se opmerkings en sal self later argumenteer vir hierdie ekklesiologiese en teologiese karakter, maar gebruik graag die begrip 'professionalisering' in belang van die publieke, maar ook teologiese, noodsaak dat predikante gekwalifiseerd, bevoeg en bekwaam moet wees. Gemeentes mag weet dat predikante "ministers by profession" is. Vir die gevare hieraan verbonde is ek net so sensitief as wat Schner in sy tradisie, en natuurlik ook ander, is ${ }^{6}$. Hy is myns insiens korrek wanneer hy byvoorbeeld skryf dat wanneer 'professioneel' sinoniem word vir 'spesialis' en 'duur', word die assosiëring van die begrip met 'geloofwaardig' en 'devoted' uitgedaag (Schner 1993:4-21). Heitink merk ook tereg op dat professionalisering ' $n$ medisyne met newe

$6 \quad$ Vgl. ook Schilderman et al (1995:141-163). 
effekte is (Heitink 2001:269). Dit is net billik om te meld dat Carroll self die kritiek teen professionalisering bespreek en ernstig neem ${ }^{7}$.

\subsection{Teologiese opleiding}

Die klag dat teologiese opleiding nie predikante vir die praktyk oplei nie is oud. Heitink skryf dat na 150 jaar hierdie klag nog steeds gehoor word. Hy verwys na ' $n$ verslag in Nederland wat konstateer dat ' $\mathrm{n}$ groeiende aantal predikante reeds in die eerste gemeente struikel (Heitink 2001:270). Schner erken dat die uitwerking van vernuwing in teologiese opleiding nog nie 'opgeskryf' is nie. Daar is egter, volgens hom, genoeg getuienis dat "newly ordained priests still leave active ministry, well-trained lay persons abandon their efforts to pursue ministry, and both groups experience various forms of dysfunction from burnout to despondency" (Schner 1993:59-60). Teologiese opleiding is onder druk. Schaller (1994:21) het in 1994 reeds geskryf dat

"from the perspective of the year 2018, perhaps the most far reaching bad news is the inability of today's theological seminaries to attract adequate numbers of highly competent, exceptionally gifted, deeply committed, and clearly extroverted adults born after 1965 who possess a compelling call to parish ministry... The time has arrived for a new system for enlisting, training, screening, and credentialing the next generation of parish pastors".

Kew \& White waarsku: soos wat sentra vir opleiding die postmoderne werklikheid ervaar, moet 'risk-taking' deel van hulle bestaanswyse word of "they are likely to go the way of the dinosaur (Kew \& White 1997:47)”.

Hoe ons die opleiding definieer en sien is in hierdie navorsing belangrik. Voorlopig ' $n$ enkele opmerking vanuit die werk van Schner: " $n$ eensydige "behavioral metaphor" is onaanvaarbaar. "Training" sou in so "n metafoor die hoofklem kry. Die verwerwing van vaardighede ("skills") en tegnieke is belangrik vir enige beroep, maar die "surface correctness may lack an intentional, reflective origin (Schner 1993:128)”. Teologiese Opleiding is nie 'boot camp'

7 Carroll (1986:7). Vgl ook sy verwysing na die sosioloog Moore (1970:5) se beskrywing van die ses elemente van 'n professie. 
opleiding nie. Daar is geen sin in en plek vir 'kamp-staal-in-diebediening' nie. Katerina Schuth se aanhaling van die opmerking van ' $n$ student, spreek, soos sy sê, waarskynlik vir baie ander: "the message is to play the role until you are ordained, and then you can really express what you believe (Schuth 1989:119)". Teologiese opleiding is, of behoort, meer te wees as 'n plek waar 'perde' vir die skou afgerig word.

Aan die anderkant is ' $n$ byna eensydige klem op akademiese universitêre opleiding. Gillespie verwys in sy bespreking van "why a theological education" na Kelsey se beskrywing tussen "Excellence as Paideia" en "Excellence as Wissenschaft and Professionalism". Die doel van paideia was om op te voed, te kultiveer, karakter vorming: "the aim was to form in the young the virtue (areté) they needed to exercise responsible citizenship". Wissenschaft verwys na "critical and disciplined research". Gillespie (2004:1-11) merk myns insiens tereg op dat teologiese fakulteite soms (meermale) skisofrenies tussen paideia en Wissenschaft leef ${ }^{8}$.

Voeg hierby die uitdagings en geleenthede van globalisering: "How can a Seminary change the way it teaches in light of the ultimate goal of enabling the church to be more faithful in an increasingly interdependent world - thinking globally and acting locally" (Roozen, Evans \& Evans 1996:11).

\subsection{Naam vir die beroep}

Ek het tot hier en sal nog vir ' $n$ hele aantal paragrawe die naam predikant in kursief skryf. Simbolies sou dit kon verwys na my besondere uitstaande liefde en waardering vir hierdie groep mense. Maar dit is nie my enigste rede nie. Ek gebruik eers later in hierdie navorsing ' $\mathrm{n}$ ander naam (vgl die paragrawe oor die teleologiese perspektiewe op teologiese opleiding hieronder).

\section{PERSPEKTIEWE OP ROEPING}

\subsection{Roeping en skepping}

Enige verstaan van roeping in die Christelike tradisie gryp terug op die teologie van die skepping van die mens. Binne hierdie tradisie word bely dat alle mense geroep is om op aarde God te dien. Dit doen die mens deur uitvoering te gee aan sy bedoeling (rede vir sy skepping) naamlik om namens God oor die skepping versorgend

8 Gillespie (2004:1-11). Vgl. Kelsey (1992:63-77,78-100). 
wag te hou. Aan die mens word die skepping toevertrou. Die Skepper skep " $n$ geskapene om die geskepte te versorg en bestuur. Gelowiges erken en bely dit met geskenkte insig. Ongelowiges ontken dit. Hieroor mag niemand hulle eintlik verkwalik nie. Vanweë die mens se natuurlike ontkenning dat hy ' $n$ Skepper het, ontken almal eintlik dat God hulle gemaak het en ' $n$ bedoeling met hulle lewens het. Om binne die Christelike tradisie te bely dat God Skepper is, is om as deel van die gemeenskap van die gelowiges die herskepping te bely. Iemand moes ons dit weer voorsê en voor leef dat ons gemaak is om sorg te dra vir die skepping. Deur sy liefde vir die wêreld sê Hy ons voor om die wêreld liefdevol te versorg, namens Hom. Deur hierdie voorsêende Woord bring Hy ons tot verstaan (nuwe geboorte) van Wie ons Skepper is en wie ons is. In die teologie van die Reformasie word hierna gewoonlik verwys met die uitdrukking 'die algemene priesterskap van die gelowiges'. Die gemeente is juis daarom priesterdom van konings. Herontdekking van roeping vra ' $\mathrm{n}$ deurdink van ons menswees en verstaan van ons Christenskap binne ons geskapenheid. Ons word nie uit ons menswees 'uitgeskep' in ons herskepping nie. Ons word tot ons menswees teruggeskep. Daarin is ons nuwe skepsels (vgl 2 Kor 5:17).

\subsection{Aardsheid}

Ons leer dit uit die Ou Testamentiese beskrywings van die aardsheid van mense wat 'dit tot in die openbaring in maak'. So kom mense in die Bybel in, word 'jou' storie opgeteken in God se storie. So word 'jou' storie opgeneem in God se storie vir mense in 2000 en daarna. Miskien is dit juis deel van die ekklesiologiese reformasie waarin ons deel: ons sien nie spektakulêre terugkeer na kerke nie (immers nie oral nie), maar ons hoor die goeie boodskap van mense

* wat die aarde versorg,

* teen oorlog en vernietiging 'veg' met woord en gesindheid,

* wat hulle hande vuil maak met die nood van ander,

* $\quad$ wat opstaan vir reg en regverdigheid,

* $\quad$ wat die gebrokenheid rondom hulle nie ontvlug nie,

* wat nie van nood af weg 'immigreer' nie, maar met die prysgawe van vryhede soos oop deure en 
vensters, van agter jou eie vrees, 'n verskil probeer maak (Sider, Olson \& Unruh 2002).

' $\mathrm{n}$ Populêre reformasie is dit ook nie 'meteens' nie. Hierdie land se verlede van geestelikheid, dikwels sonder aardse betrokkenheid, lê nog te vars in ons geheue. Die vleeswording van die Woord behoort ons teologiese motivering vir die voortsetting van hierdie reformatoriese beweging te bly.

\subsection{Prakties-teologiese aanpak}

Ek het aanvanklik gedink om te reflekteer op Ou-Testamentiese, Nuwe-Testamentiese, sosiologiese en bedienings perspektiewe op roeping. $\mathrm{Na}$ ' $\mathrm{n}$ literatuur ondersoek lyk dit vir my nuttiger om eerder, in ' $n$ meer sistemiese wyse, te fokus op prakties-teologiese perspektiewe op roeping. Die volgende stelling is in ' $n$ bepaalde sin "n teologiese vertrekpunt: "the pastor serves the priestly commission God has given to the entire congregation (Johnson 1998:89)". My ondersoek het my basiese hipotese bevestig: Wanneer die identiteit van die gemeente verstaan en gesoek word, val die bediening in plek - ook die bediening van die plaaslike predikant.

In hierdie navorsing word later teruggekom na die belangrike werk van Farley (1983). Ek sluit hier aan by 'n opmerking, in ' $n$ ewe belangrike boek, wat tegelyk Farley bespreek en ' $n$ eie teorie uitwerk. Hough en Cobb stel dit as 'n inleidende stelling tot hulle werk dat wat vandag nodig is om teologiese opleiding te reformeer "is a strong conviction about who we are as a Christian people (Hough \& Cobb 1985:4). Hiersonder weet ons nie duidelik genoeg wie om waarvoor op te lei nie.

\subsection{Korporatiewe identiteit}

Dit mag in ons nadenke oor hierdie saak die sterkste teologiese vertrekpunt wees: die korporatiewe identiteit van die gemeente. Die roeping van Abraham om ' $\mathrm{n}$ 'volk' te word, mag ons nie mislei om roeping eensydig te individualiseer nie. Toe die 'een' die 'baie' geword het, het die 'baie' nooit weer die 'een' geword nie. Die tweede Adam leef en sterf as Een van die 'baie' wat toe reeds ' $n$ werklikheid is - in watter vervormde toestand ook al. Die volk van God is die mense deur wie Hy sy plan uitvoer. Hy is met die wêreld besig en die gemeente kom slegs tot selfverstaan (hoe kompleks hierdie identiteit ook al is) binne die plan van God met die wêreld. God soek en verkies om te soek en te vind. Hy is met sy gemaakte 
werklikheid besig. Hy skep ' $n$ nuwe werklikheid, sy vergadering, sy kahal, sy ekklesia, want Hy gaan enduit deur met sy werke(likheid). 'Volk van God' is eintlik nie as naamwoord te verstaan nie, maar as werkwoord van God se aktiwiteit. God was en is oral skeppend en heelmakend (reddend) teenwoordig en aan die werk. Sy werk is divers. Dit is soms moeilik om te onderskei tussen hoe Hy in die werk van Amos en die werk van Socrates aan die werk was. In die kerk, as mense van God in wie en deur wie Hy werk, behoort dit deursigtig duidelik te wees dat Hy aan die werk is - al bly dit moeilik om altyd die hoe en waarom te verstaan. Hough \& Cobb noem Israel tereg 'n gemeenskap wat gekonsentreer het op God se aktiwiteit. Juis dit maak van God se aktiwiteit "an event of worldhistorical significance... For us, placing the church in a worldhistorical context is placing it in the context of God's creative and redemptive activity. The question is, in what way does the church express, embody, and witness to that activity? (Hough \& Cobb 1985:20-21)". Elke leser van die Bybel het dit al opgemerk: die roeping van individue soos Josef, Moses en baie ander word telkens gemotiveer deur die 'behoeftes' van die baie. Die roeping van Moses is hiervan 'n unieke voorbeeld (Eks 3, 4).

\subsection{Metaforiese verstaan van die kerk}

Hierdie werkgemeenskap in diens van die werk van God word in die Skrif metafories verhaal. Metafore vertel altyd iets van die geheel sonder om alles, of die geheel, te vertel. Die verhale waarbinne die metafore verpak word, help ons om te verstaan wat die metafoor, wat die verhaal help vertel, opklaar ten opsigte van die wese of identiteit van die kerk of gemeente. Dit is nie hier die plek om die metafore van die Skrif te ontleed nie. Dit is deur baie ander gedoen en my eie werk verwys dikwels daarna ${ }^{9}$. Die bedoeling is eerder om die uitdaging van identiteitsverstaan en -vinding te beklemtoon. Identiteit en identiteitsvinding is in my eie teologiese nadenke ' $n$ integreringsprinsipe ${ }^{10}$. Dit is nie " $n$ ontvlugting uit die komplekse aard van ons bedieningsprobleme nie. Dit is wel ' $\mathrm{n}$ poging om ' $\mathrm{n}$ integreringsprinsipe te vind. Die bedoeling is nie om te beweer dat 'iemand' presies weet wie die kerk is en daarom al die oplossings

$9 \quad$ Vgl Minear (1977); Nel (1994:1-94); vgl ook die Engelse vertaling van hierdie werk Nel (2004).

10 Vgl die bespreking van Christus as 'punt van oriëntering' in ons nadenke oor die Kerk: Schippers (1982:96-105;181-192; 211-224). 
het nie. Wie egter vanuit hierdie kern waarheid begin dink, vind, weliswaar met moeite, rigting in die soeke na rigting. Dit is kompleks en moeilik om die identiteit van die gemeente te beskryf. Eenduidig en simplisties kan dit nie gedoen word nie. Die kerk is ' $n$ multi-dimensionele werklikheid. Die plaaslike gemeente as kontekstuele werklikheid nog meer so. Dit bly egter ' $n$ uitgangspunt dat "the church as a whole must manifest its own nature in its ministry, and determine to train its ministry accordingly ${ }^{11}$ ".

\subsection{Korporatief betrokke by wat God doen}

Wat binne die verband van hierdie navorsing van spesifieke belang is, is die perspektief op identiteit vanuit die korporatiewe karakter van roeping tot betrokkenheid by die voortgaande skeppende en herstellende aktiwiteit van God in die wêreld. Hierdie perspektief, hoewel soms eensydig asof op die kerkwerf alleen, word in die reformatoriese teologie verstaan as die algemene priesterskap van die gelowiges. ' $n$ Opmerking van Barry, in sy openingsrede tot die bekende konvokasie van Lutherane, beklemtoon die korporatiewe karakter en belang van hierdie priesterskap en die verband daarvan tot die rol van die predikant. Die agtergrond van sy opmerking verhoog die waarde van die stelling. Hy verwys naamlik na ' $n$ stelling uit 1844 waar geïdentifiseer word dat "voluntarism, that is, individuals freely choosing to do things - is the 'central motif marking religion in America"". Sy stelling dan: "Whenever church life is seen largely to consist of persuading loosely-associated individuals to pull together in the same direction, the Office of the Ministry cannot help but be affected. As one writer put it already in 1850, 'The minister is often expected to be, for the most part, a manager of social utilities, a wire-puller of beneficent agencies ${ }^{12}$ ", Die gemeente as gemeenskap van priesters is hiervoor deur God bedoel. In die Bybel word hierna ook verwys as die heiligheid van die kerk: hiervoor bedoel (vgl byvoorbeeld 1 Pet, veral 2:9-10, vgl Congar 1967).

11 Working Party on Assessment of the Committee for Theological Education (1987:27).

12 Barry (1998:6). Sy aanhalings is uit Lee (1987:157) en Hofstadter (1963:86). 


\subsection{Uit genade ingeroep}

Die wese van die gemeente omvat die roeping van die gemeente. In die metafoor van 'n oorlog is die gemeente nie huursoldate wat in opdrag van 'n regering (wat nie hulle eie is nie) 'n opdrag uitvoer nie. Die wyse waarop die gemeente 'geword' het wat en wie hulle nou in Christus is, is deurslaggewend vir die verstaan van identiteit binne die geloofsgemeenskap. Niemand het aansoek gedoen vir dissipelskap nie. Wie geloof bely, bely dat 'jy' ingeroep is tot nuwe status en nuwe roeping. Die genade-karakter van God se werksaamheid is hier van kritiese belang. Anders het 'ek' geen hoop om roeping te verstaan nie: nie die van die gemeente nie en ook nie 'my eie' nie. Wanneer die gemeente nie weet wat hulle 'primêre status' is nie, weet hulle ook nie wat die kerk se 'primêre besigheid' is nie. Dan weet predikante ook nie wie hulle is en wat hulle 'primêre roeping' is nie. Jy sou kon sê dat gemeentes hulle onwetend (niewetend) voortgebring het. Die plaaslike geloofsgemeenskap aanvaar ook nie verantwoordelikheid vir die 'volwassewording' van die roeping en geroepene nie. Geroepe 'babas' word op die stoep van die denominasie gelaat.

\subsection{Tot diens ingeroep}

Die Bybel is vol van verhale oor die leiers vanuit, binne en vir die volk van God. Binne die reformatoriese tradisie is skerp gereageer teen hiërargie en dwingelandy, maar nie teen die bestaan van die 'diensleiers' nie (Heitink 2001:271-273). Soos vooraf verklaar, is my bedoeling nie om die óf en óf nie van die 'ampte' te beredeneer nie. Ek aanvaar dit (Nel 1994:49-59). Wat wel ter sake is, is die verstaan van hulle roeping binne die gemeente as die primêre geroepenes van God. Aan die wortel van die Bybelse begrip 'roeping' lê die waarheid dat God self, op sy eie wyse en vir sy doel, mense roep (Schmidt 1965:489). In hierdie navorsing hou ek die uitgangspunt vas dat die 'amp' nie maar uit die gemeente opkom nie. Dit het in die hart van God 'opgekom' om vanuit die gemeente aan die gemeente te gee "sommige as apostels, ander as profete, ander as evangeliste, ander as herders of leraars" (Ef 4:11). So was dit nog altyd: God 'noem' of 'roep'; Hy 'benaam' (Gen 17:19); Hy nooi uit (kalein soos onder andere in die Griekse literatuur); Hy roep op tot ('summon') (Hand 4:18; 24:2). Om dit met 'n paar sinne van Schmidt te sê: "Kalein is a technical term for the process of salvation... The God of the Bible is a person confronting (in die sin van ontmoet $\mathrm{MN}$ ) persons...[F]ullest expression at 2 Tim 1:9 brings 
out particularly that our concern here is with a pure act of grace on the part of God (Schmidt 1965:489,490,492). Treffend is sy verwysing na die gebruik van die konsep 'kleitos' (geroepene) as sou dit beteken: 'Christian Apostle' (Schmidt 1965:494). Ridderbos het lank gelede al geskryf dat ons roeping ons manier van bestaan is: "For those who thus have been called according to the divine purpose (Rom 8:28), the preaching of Christ the Crucified One is the power of God and the wisdom of God (1 Cor 1:24). It is this 'faith of God's elect' (Tit 1:1) which forms the mode of existence of the new life through the Spirit" (Ridderbos 1975:236).

In die literatuur rondom die predikant en sy opleiding is daar tereg 'n pleit vir, wat genoem kan word, die 'selfstandigheid' van die "Office of the Pastoral Ministry". Johnson argumenteer vanuit die Lutheraanse tradisie. Luther het, te midde van sy beklemtoning van die algemene priesterskap van die gelowiges, altyd die noodsaak van die "ordained ministry" beklemtoon: "Although we are equally priests, we cannot all publicly minister and teach ${ }^{13}$. Dat die gemeente primêr is in die koms van God na die wêreld en dat God aan die gemeente 'diensleiers' gee, staan nie teenoor mekaar nie. Daar is wel ' $\mathrm{n}$ spanning in hierdie waarheid. Dit is " $\mathrm{n}$ bipolêre waarheid, en bly alleen binne hierdie bipolêre spanning die waarheid. In hierdie bipolêre spanningsveld is die gemeente, as gawe van God aan die wêreld, ' $n$ 'eerste' in twee gelyke waarhede. Sentraal in albei pole is dat God gee, in belang van sy skeppings en -heelmakende aktiwiteit in die wêreld voorsien (gee) Hy. Die gemeente as grootheid huisves die grootheid van die gawes van God - in belang van die gemeente en sy betrokkenheid by die werksaamheid van God. Op hierdie waarheid sal weer en weer binne hierdie navorsing teruggekom word.

\section{BEDIENINGSPERSPEKTIEWE OP ROEPING, WER- WING, KEURING, OPLEIDING EN ORDENING}

\subsection{Wat die beroep behels}

Ek wil graag die hele debat oor wat die beroep behels (en waarvoor 'personeel' gesoek word) onder hierdie hoof beskryf. Dit is myns insiens konsekwent met my vertrekpunt hierbo naamlik dat 'amp' en 'gemeente' en 'identiteit' nie geskei kan of mag word nie - en selfs met groot omsigtigheid onderskei moet word. Dit gaan oor

13 Aangehaal deur Johnson (1998:88). Vgl Luther (1520:356). 
bediening: oor dit wat namens God in Christus, en deur die Gees, gedoen word. Dit gaan oor dit waarmee die gemeente besig is. Oor hoe die gemeente deelneem aan die werksaamheid van God. Oor of en hoe die gemeente ingeskakel is by die voortgaande skeppende en heelmakende aktiwiteit van God. Laat dit net nog ' $n$ keer gesê word: hierdie ingeskakelheid het alles met roepingsverstaan te doen. Die vraag binne Christenskap is nie 'kerk' nie, maar 'wêreld'. Die gemeente en kerk (in verband) vind plek binne die verstaan van hoe gelowiges 'in die wêreld', waar ons ons beroepe beoefen, deelneem aan dit waarmee God besig is. Terwyl daar ' $n$ 'verpligting vanuit die liefde' op gelowiges rus om die wêreld te begelei om God in Christus te leer ken, is die taak van die gemeente nie om die 'kerk' te laat groei nie. Die roeping is om gelowiges te help om, met nuwe begrip van God en hulleself, in die wêreld te bly (in baie gevalle daarheen terug te gaan) en daar God se verteenwoordigers te wees.

\subsection{Gemeente as bedieningswerklikheid}

In die teologie word meermale na hierdie verstaan van bediening verwys as die "laïcale grondmodel". Met "n aanhaling uit "n rapport van die gereformeerde kerke in Nederland skryf Heitink: "Vanuit die verskeidenheid van die gawes wat God aan die gemeente en haar lidmate geskenk het, sal ons die gemeente as die draer van alle bedoelinge van God moet sien" (vry vertaal MN) (Heitink 2001:190). Hierdie insigte was en word steeds baie beïnvloed deur die drang na demokratisering van die samelewing. Die kerk is as't ware deur die sosiale veranderinge verplig tot herontdekking van hierdie teologiese kern in die verstaan van bediening. Die uitdaging is nou om vas te hou daaraan dat net soos die heil nie uit die gemeente opgekom het nie, so ook nie die 'amp' nie. Die 'amp' is, binne hierdie verband van die gemeente as primêre draer van die bedoeling van God, die bewaker van die bedoeling van die kerk (Firet 1987).

Die gemeente is ' $\mathrm{n}$ bedieningswerklikheid. Hierdie bediening is teologies te verstaan en te 'bemeester'. Van hierdie werklikheid is elke gelowige deel. Ons is deur die doop tot bediening georden. Deur Woord en Sakrament word dissipels tot makers van dissipels. Dit is ons bediening. Elke predikant is eerstens deel van hierdie bedienende gemeente. Wat ook al die wese van die 'amp' daar is voorafgaande werklikhede wat dieselfde is: deelgenootskap aan die gemeente as werksvolk van God. Met dit in gedagte: wat is dan die 'ekstra' in die lewe van die wat tot 'voltydse bediening' geroep 
word? Hieroor moet ons duidelikheid hê indien ons wil weet wie word gesoek, wie word waarvoor opgelei, wie kwalifiseer uiteindelik en waarvoor.

\subsection{Naam en saak}

Ek bedoel nie om te sê dat die name wat predikante gedra het en nog dra, altyd 'sê' wie hulle is nie. Tog vertel die name hoe daar oor hulle gedink was en nog gedink word. Dit is ook pogings om te onderskei wat hulle onderskei van mense wat eweseer kwalifiseer om die name te dra en die take te verrig. Selfs 'voltyds' onderskei hulle nie. Alle Christene is voltyds in diens. Miskien is dit nodig om vooraf een onderskeiding te probeer vestig: die meer offisiële publieke karakter van hulle bediening onderskei hulle van die van die meeste ander gelowiges (Wood 1994:12-13). Baie ander gelowiges is selfs meer publiek, het groter 'platforms' vanwaar hulle bedien, maar nie almal is offisieel deur die res van die 'gemeente as draers van God se bedoeling' gevra en toegelaat om dit te doen nie. Jy sou dus kon sê dat die predikant nie maar net namens God nie (want dit doen alle gelowiges in bediening), maar ook namens 'ons' (wat almal in bediening is) mag bedien - waar en soos 'ons' dit kontekstueel nodig vind ${ }^{14}$. Saam hiermee gaan natuurlik ook ander sake, maar hierdie onderskeiding is wel krities.

Dit is nie hier nodig om enigsins vollediger in die geskiedenis van die 'amp van die dominee in te gaan nie. Die reeds aangehaalde werk van Heitink sal in hierdie verband vir " $n$ lang tyd " $n$ standaard bron bly ${ }^{15}$. 'n Opmerking wat in die verbygaan gemaak moet word, is die opvallende invloed wat veranderinge in die samelewing op die verstaan van die 'dominee' gehad het. My doel is om kortliks die name wat op ' $n$ bepaalde wyse (soms baie kontekstueel) uitdrukking gee aan die 'beroep' te noem en bespreek. Laat my voorlopig 'n paar noem:

* Die 'leermeester' (leraar) staan hoog bo-aan hierdie lys. Gegewe die rol van die kategese in die vroeë kerk (Dingemans 1978:159-177) is hierdie beklemtoning

14 Wood (1994:13) noem dit 'ecclesially comissioned, typically fulltime, and normally exercised in relation to a congregation of local Christian community'.

15 Vgl veral die drie kolom opsomming van die bewegings in die geskiedenis in Heitink (2001:257-261). 
verstaanbaar. Dit bly ook belangrik. Die predikant het ongelukkig onder andere as gevolg van hierdie naam die posisie van 'Meester' gekry en dikwels omhels: "ich bin Herr Pastor!' I am 'lord' Pastor! (Kalthoff 1998:134). Hierdie sosiologiese ontwikkeling binne 'n groeiende groep 'ongeleerdes' in die middel eeue en nog steeds is ook verstaanbaar. Die groot vraag bly of dit die wese van die predikant beskryf of wel een van sy funksies?

* Nog sodanige name is liturg en prediker. Historiese gebeure soos byvoorbeeld voor en tydens die Reformasie verklaar dikwels waarom ' $\mathrm{n}$ bepaalde funksie begin om die beskrywing van die wese te word. Net so relevant is die gevaar dat ons nou die herontdekking van vervaagde funksies (soos byvoorbeeld die van liturg) mag verwar met die herontdekking van die wese van die 'beroep'.

* Die naam pastor is, volgens sommige (Kalthoff 1998:143), die mees gebruikte naam vir die beroep. Die populariteit van die naam vandag het verseker ook te doen met die privatisering, individualisering in die samelewing en die prominensie van hulpverlening in die 'Kliniese Pastorale Vorming' (Heitink 2001:200). Hierdie naam dra meer as funksie. Dit behoort meer so tot die wese van die beroep as ander en ek kom hieronder weer daarna terug.

\subsection{Diens as saak}

Die begrip wat die wese van die bestaanswyse van die gemeente beskryf, beskryf ook die beste die wese van die 'beroep' waaroor dit hier gaan: diens. Hierdie mense is in die bediening. Dit bring ons terug na wat dan hulle bediening onderskei van die bediening waarin alle gelowiges staan. Die vraag is nou nie of hulle nodig is en daar moet wees nie. Ek aanvaar dat die 'amp' in hierdie sin nie uit die gemeente opkom nie, net soos die heil nie uit die gemeente opkom nie $^{16}$. Die vraag is na die bedoeling van die diens van die persone wat die wese van hulle diens (as dienaars) met die gemeente deel. Hieroor meer:

16 Vgl Heitink (2001:273) en sy verwysing na Berkhof (1973): "het ambt drukt uit dat het heil niet opkomt uit ons eigen midden, ook niet uit een christelijk midden". 
* Hierdie persone is geroep om, volgens die patroon van die diens van die Christus, God se diensknegte te wees. Die wese van hierdie beroep is om oortuig te wees (en om hierdie oortuiging aan onderskeiding te onderwerp soos hieronder beredeneer) van 'hierdie mens' se gegewenheid, sy karakter as geskenk, ' $n$ dienskneg in die gestalte van ' $\mathrm{n}$ 'doulos tou Christou'. Die wese van hierdie roeping lê daarin dat ons geroep is om ander wat dien te dien: dienaar, in diens van God, in diens van dienaars van God. Walther onderskei, binne sy Lutherse tradisie, in sy sewende stelling die 'amp' van die predikant. In die vierde stelling beklemtoon hy dat die 'amp' nie heiliger as die van die ander gelowiges is nie en nie om daardie rede spesiaal is nie. Dit is ' $n$ 'amp' van 'diens' (wat natuurlik in Afrikaans ' $\mathrm{n}$ toutologie is). Hy beklemtoon in geen onduidelike taal dat die 'amp' nie opsioneel is nie, God het dit ingestel (stelling 2). Maar, sê hy dan in stelling nommer sewe: "The holy Preaching Office is the power, conferred by God through the congregation, as the possessor of the priesthood and all church power, to exercise the rights of the spiritual priesthood in public office in the name of the congregation ${ }^{17}$ ". Die bekende Henry Nouwen koppel die naam 'minister' (dienaar) op ' $\mathrm{n}$ besondere manier aan hoe die persoon in hierdie diens aan Christus herinner. Hy verwys treffend na die "minister as a healing reminder... the minister as a sustaining reminder..., (and the) minister as a guiding reminder" (Nouwen 1977:17,37,57).

* Binne hierdie ontwikkeling val die lig toenemend helder op die didache-funksie van die dienaar van dienaars. Die wese verplig tot die funksionele vraag: waarmee en waarin kan die 'publieke dienaar' die ander dienaars van God in die samelewing tot diens wees? Diensknegte van God (as deur God gewil en ingestel) is dan ook tot diens van die gemeente. Sommige sou sê in diens van die gemeente. In ' $n$ bepaalde sin is dit ook

17 Walther (1987:21-23). Vgl vir die bespreking van tese 2 (34-37) en tese 7 (87-100). 
waar, solank dit sonder verlies van die verstaan van die wese van 'geskenktheid' is. Met verwysing na kerkordes van sy land en na die kerkreg kenner Koffeman, haal Heitink die ouer formulering, waarin steeds baie waarheid sit, aan: predikante werk ten dienste van die gemeente, maar is nie in die diens van die gemeente nie (Heitink 2001:229). Hierdie "bijzonder soort van vrij beroep"-beskouing is almeer onder druk. Die 'mondigheid' van die gemeente en die gemeente se sentrale, eweneens deur God geskenkte, rol in die plan van God, maak dit nie meer moontlik om dit slegs só te sê nie. Ridderbos het reeds gesê, die 'amp' is "uit Christus deur die gemeente" (vry vertaal MN) (Ridderbos 1973:534).

Vir hierdie verstaan van die wese van die 'publieke bediening' van die bedienaar, ten dienste van die gemeente, is die verstaan van die wese van die gemeente onontbeerlik: die gemeente (al die lidmate), 'ons' is dienaar van God in hierdie wêreld. Geen hervorming in die beroep van die predikant is moontlik sonder hierdie gelyktydige reformasie in die identiteitsverstaan van die gemeente nie.

* Wat vra Christus van ons? Hierdie vraag is belangrik vir die bepaling van die taak, doel of missie van die 'amp' (Heitink 2001:273). Help sodanige teologiese vraag ons ook met die verstaan van die wese van die 'amp'? In die woorde van die belydenis is ons in Hom deur die Gees gesalf tot priesters, profete en konings ${ }^{18}$. Histories is die antwoord meer dikwels funksioneel hanteer (as synde dit wat ons moet doen) as ontologies, verwysend na ons wese. Die wese ook hier is die van diens. Wanneer dit gesnap word, verruim dit, soos Heitink in aansluiting by Jan Hendriks dit stel, alle handelingsmoontlikhede ${ }^{19}$. Voorlopig gaan dit hier nog om wese. In die wese van wie 'ampsdraers' in Christus is, lê die verstaan van 'publieke bedienaar' as priester,

18 Heidelbergse Kategismus vraag en antwoord 32.

19 Heitink (2001:273) met verwysing na Hendriks (1999). 
profeet en koning. Dit is alle Christene, maar dit is die 'publieke bedienaar' ook. In Christus vind die gemeente haar identiteit, in Hom ook diegene wat deur God aan die gemeente geskenk is. Hierdie geskenkte persoon, wat sy/hy ook al genoem word 'staan nie meer bo die gemeente of buite die gewone lewe nie, maar is ' $\mathrm{n}$ lid soos al die ander, met eie gawes ten dienste van die geheel' (vry vertaal uit die Nederlands MN) (Heitink 2001:226).

* Bogenoemde word in die Bybel gedra deur die begrip van dissipelskap. Hierdie begrip, wat lank die vroeë Christene beskryf het, is kern belangrik in die verstaan van die verband identiteit van die gemeente en identiteit van die predikant. Hierdie lyn loop deur drie van die werke waarna reeds hier verwys is (of nog na verwys sal word) en wat direk met die oog op teologiese opleiding geskryf is ${ }^{20}$. Vir die doel van hierdie navorsing is die verband tussen dissipelskap en dissipelmaking belangrik. Lidmate is dissipels. Immers so behoort dit te wees in gemeentes wat met lidmaatskap erns maak ${ }^{21}$. Die gemeente se roeping is om dissipels te maak. Dit vra ' $n$ dissipel en dissipelmaker om dissipelmakers te help om dissipels te maak. Daar is geen manier om hiervan weg te kom nie. Die verband leerling/leer/dissipelskap is in die Skrif onlosmaaklik verbonde (Rengstorf 1967:400-412). Die vraag na wat Christus van ons vra is eintlik eenvoudig. Dit vra wel voortdurende interpretasie (en dit is kompleks), maar die basiese vraag het eintlik nog nooit verander nie. By ons eie tolhuisies word ons daagliks gekonfronteer met die vraag/oproep: "Volg My" (Matt 4). Die verwysing na die pastor as leraar spruit voort uit hierdie dimensie soos wat dit verband hou met die modus van die didache. Dit is nie hier nodig om in diepte in te gaan op wat verkeerd geloop het nie. Dit het onder andere te doen met die sameloop van omstandighede: die 'leermeester' in die tyd van ongeleerdheid. So word die

20 Ek verwys spesifiek na die werke van Schner (1993); Hough \& Cobb (1985); Wood (1985).

$21 \quad$ Vgl Nel (1994:84-96); Watson (1981); Dunn (1992). 
leermeester, die opvoeder van dissipels, maklik tot 'Herr Professor'. In die Nuwe Testament lê die klem op die 'toerusting' van gelowiges aan wie die opbou van die gemeente toevertrou is. Die pastor is opleier in die midde van die gemeente van dissipels "with Christ in the school of disciple building" 22 .

\subsection{Opsommend en samevattend}

Waaroor gaan dit dan in die 'amp' van die 'publieke dienaar' ten dienste van die gemeente as primêre draer van die bedoelinge van God? Die opsomming hieronder volg 'n lyn saamgestel uit baie ander werke, in ' $n$ orde wat ekself daaraan verleen en raak op meer as een manier die 'soort' gawes waarna gesoek word in hierdie 'beroep'.

\subsubsection{Beginpunt: Identiteitsverstaan}

Dit is inderdaad moeilik om te sê wat in hierdie 'waaroor gaan dit nou eintlik' eerste kom. Tog is daar ' $n$ beginpunt in die identiteitsverstaan van die gemeente as ' $n$ netwerk van verhoudings. Myns insiens gee die verbondsmatige denke in die Bybel daartoe aanleiding. Die mens word geskep om met God en met 'die ander' in verhouding te leef. Die Bybelverhaal oor die skepping en die naamgewing deur die mens vertel al hiervan. Die mens bestaan verhoudingsmatig. Die skepping en herskepping getuig daarvan. Die gemeente is gewoon die gemeenskap (verhoudingswoord) van mense wie se verhoudings herstel is en voortdurend in ' $n$ proses van herstel is. Die 'publieke bedienaar' moet dit verstaan. So iemand is ' $n$ verhoudingsbemiddelaar namens die gemeenskap van mense wie se verhoudings in ' $n$ proses van herstel is. Dit is myns insiens die gemene deler in die wese van die bediening waartoe hierdie roeping wys: dit is ' $n$ werk met mense. Ek het in ' $n$ vorige artikel so daarna verwys: 'die saak is dat die predikant/leraar/pastor in ' $n$ mens-beroep staan' (Nel 2002:160). Lidmate sê almeer so. In 'n profiel soos deur gemeentes opgestel en waarna Heitink verwys "blijken communicatieve vaardighede hoog te scoren" (Heitink 2001:227). Hierdie uitgangspunt is inderdaad ook keuringsprinsipe. In ' $\mathrm{n}$ publikasie wat omvattende navorsing oor meting vertolk, word sò na

22 Wilson (1979). Vgl ook die hoofstuk oor "Authority in Ministry" in Reumann (1987:165-185). 
"competencies" verwys: "Competencies refer specifically to interpersonal relational dimensions that affect others. Examples of competencies are listening skills, abilities to communicate ideas and feelings accurately, maturity of judgement, and other abilities that enable groups to function effectively"23.

\subsubsection{Deel van gemeente se bestaansdoel}

' $n$ Tweede prioriteit is die verstaan van die roeping (missie of bestaansdoel) van die gemeente in die wêreld en 'jou' deel wees van hierdie groep geroepenes. Reeds in 1956 skryf Niebuhr in ' $n$ werk wat nog steeds in kerklike materiaal in die VSA neerslag vind dat daar vier komponente in die proses van roeping is: 'the call to be a Christian, the secret call, the providential call, and the ecclesiastical call' (Niebuhr 1956:64). Wie dit nie ernstig neem nie, dink dikwels dat die 'publieke bedienaar' eerste was en voorrang bo die gemeente verdien en geniet. Insig in wie die gemeente is (die gemeente waarvan ons deel is) help ons in ons nadenke oor ons wese. Dit lei tot ' $\mathrm{n}$ verstaan van wat Peterson noem 'on being unnecessary' (Dawn \& Peterson 2000:1-20). Peterson verwys na sy eie 'in herinnering roep' van sy roeping tydens en rondom die veertigste herdenking van sy ordening. Die sesde vraag wat in sy denominasie aan hom gevra was lui soos volg: 'Will you, in your own life, seek to follow the Lord Jesus Christ, love your neighbors, and work for the reconciliation of the world?' (Dawn \& Peterson 2000:12). Natuurlik is dit ' $n$ vraag vir alle gelowiges. Maar dit is juis die punt. Wie nie sy/haar deel wees van alle gelowiges ernstig neem nie, kan op die duur vir geen gelowige iets beteken nie. Die ander sewe vrae verwys meer na die spesifieke van die 'amp'. Peterson noem hierdie 'vows' die 'beskermers' (soos die apparaat van rots klimmers) in die bediening. Die gevaar (onbeskermde toestand vir 'ampsdraers') "has to do with becoming so diligent in being a pastor, working for Jesus, that it crowds out the personal life of living for Jesus. The operative phrase is the sixth vow is "in your own life" (Dawn \& Peterson 2000:13, 14). In hierdie opsig noem Dawn in haar refleksie op die brief aan die Efesiërs hierdie 'publieke bedienaar' "a living doxology" (Dawn \& Peterson 2000:41). 'Ampsdraers' is deurdrenk van 'n gemeente-verstaan, " $n$ gemeente waarvan ek ' $n$ lewende lid is om God te verheerlik. In die belangrike bydrae van Hough en Cobb

23 Hunt, Hinkle (Jr.) \& Malony (eds) (1990:13). 
word hierdie dimensie van gemeentewees myns insiens tereg uitgelig as wesenlik tot die verstaan van die gemeente en die liturg/predikant. Hulle beskryf treffend die verband tussen aanbidding en missie en hoe dit tot ' $n$ groot mate bepaal of die kerk Christelike kerk is of nie. Belangrik, in direkte verband hier, is die feit dat die kerk ' $n$ gemeenskap is wie se geskiedenis bepaal is 'by the memory of Jesus Christ' (Hough \& Cobb 1985:77). Schner, wat in hierdie verband Hough/Cobb aanhaal en by hulle aansluiting vind, sê "that the act central to the Church is the celebration and renewal of the memory of Jesus" (Schner 1993:41). Die missionêre bepaaldheid van die kerk en die verband hiervan met teologiese opleiding word in literatuur al duideliker. Banks skryf sy hele boek vanuit die perspektief dat daar ' $n$ 'missional alternative' tot die huidige modelle van teologiese opleiding is. Guder werk met dieselfde vertrekpunt en pleit vir ' $\mathrm{n}$ missionêre hermeneutiek in die lees van die Bybel $^{24}$.

Twee sake staan hier voorop: die gemeente is in die bediening en binne hierdie geroepte gemeente roeping is 'ek' eintlik die noodsaaklike onnodige. Peterson se invalshoek lê op 'n geestelike vlak en moet binne hierdie verband waardeer word. Dit is nie die bedoeling van die boek om die 'amp' onnodig as sou die gemeente daarsonder kan klaarkom (as oorbodig) te beskryf nie. Juis andersom: sonder watter kwaliteit pastor (hulle woord) kan die gemeente nie goed gemeente wees nie? Wanneer Heitink na hierdie werk verwys, sê hy 'mijn insteek is nuchterder'. Direk na die paragraaf demonstreer hy dan in kolomme (histories verantwoord) wat die rol van die dominee (sy woord) se taak op macro-, meso- em mikrovlak was en ook huidiglik kan wees (of selfs behoort te wees) (Heitink 2001:255-261). Die doel is om mee te werk aan nuwe wesensverstaan en plekvinding in die samelewing waar die beroep 'meer en meer onsigbaar' (Heitink) word. Die titel van sy hoofstuk waarbinne voorafgaande vermeld word is: "Om de toekomst van een 'overbodig' beroep". In sy inleidende paragraaf verwys hy na die postmoderne kultuur waar die verstaan geld dat die pastor van die toekoms diegene is wat ophou om pastor te wees (Heitink 2001:255).

24 Banks (1999:129-248); Guder (1998, 2000 \& 2002). Vgl. ook die 'Festschrift' vir Hans Kasdorf en veral Deel II: Holthaus \& Müller (Hg.) (1998:35-94). 


\subsubsection{Teologiese hart van die 'amp'}

' $n$ Derde prioriteit in die verstaan van die 'publieke bediening' is die soeke na ' $n$ teologiese 'hart' vir die 'amp'. My oortuiging is dat dit in die begrippe diens en pastor lê. Natuurlik is die keuse ook kontekstueel gemotiveerd. Tog is daar baie goeie teologiese argumente wat dit meer maak as slegs ' $\mathrm{n}$ tydsgebonde keuse. Die Ou Testamentiese verstaan van die opdrag by die skepping dra alle tekens van sorg en versorging. Die roeping van Moses, soos in Eksodus verhaal, is vol van God se deernis vir mense wie se nood Hy raak sien. Die uittog word herderlik verpak. Die Koning se roeping, wat so treffend in die Koningspsalm 23 neerslag vind, wys in hierdie rigting. Die Lukas 15 samevatting van die evangelie binne die evangelie beklemtoon hoe belangrik hierdie verstaan van die kerk vir Jesus is. Die 'herstel' van Petrus op die strand in Galilea vertel van herderlike versorging soos min ander gedeeltes (Joh 21). Die verwysing van Petrus na die ouderlinge as herders in navolging van die Herder (1 Pet 5), die woord van Paulus aan die ouderlinge van Efese (Hand 20:28), die moontlikheid dat Efesiërs 4:11 vertaal kan word as 'sommige as herders of leraars', en nog meer is maar net enkele sodanige Bybelse verwysings. Dit is verstaanbaar dat kerke in die Engels sprekende wêreld lank reeds verkies om na die 'Public Office' in hulle gemeentes te verwys as 'pastors' (Kalthoff 1998:143). Die koppeling in die Nuwe Testament van die herderskap met ons koninklike priesterskap is netjies en opvallend. In hierdie begrip, soos deur Jesus gevul met die bekende woorde van Johannes 10, lê ook die hart van diens: lewe aflê. In navolging van Christus beteken diens altyd lewe gee - nie alleen in die sin van sterf nie. Daar is ' $n$ wonderlike dinamiek in lewe gee. In die gee van 'my' lewe aan ander, gee 'ek' ook lewe aan ander. Dit is die verstaan van diens wat ons intrek in die besigheid van God: lewe gee, lewe herstel, lewe teruggee, nuwe lewe gee, ewige lewe 'gee'.

\subsubsection{Leiding as pastorale diens}

Heitink, in aansluiting by Jan Hendriks, reflekteer op wat ek as vierde prioriteit in die verstaan van die wese van die 'amp van publieke bediening' noem: leiding as pastorale diens. Binne hierdie verstaan word gelykheid en die 'teenoor' ernstig geneem. Die woorde "geloofwaardig en dienstvaardig" word so die kern van "een hoogwaardige ambtsopvatting" (Heitink 2001:273). Om leierskap te 
aanvaar, word meer en meer as deel van die 'publieke bediening' van die pastor aanvaar ${ }^{25}$. In baie publikasies word dit steeds as 'organisasie' of as 'administrasie' beskryf. Van der Ven gaan in diepte in op die besondere funksies van die bediening. Hy haal verskillende outeurs aan wat die funksies op verskeie maniere onderskei. In sy verwysing na die Handboek vir Praktiese Teologie verwys hy na die begrip leierskap in verband met organisasie ${ }^{26}$. Die literatuur hieroor is eintlik onoorsigtelik. Ek het vroeër probeer om die diens van leiers as deel van my verstaan van die 'amp' te beskryf (Nel 1994:49-59). ' $n$ Enkele opmerking is hier voorlopig genoeg: Almal is in diens van God en sy bedoeling met die gemeente. In hierdie verband is sommige se diens leierskap en sommige se diens is 'publieke leierskap'. Die wese informeer die funksie, ook ten opsigte van die pastor as leier of 'leiding as pastorale diens'. Laat ek dit, voorlopig, in die woorde van Heitink saam vat: Die gemeente benodig hierdie mense om as 'ampte' die identiteit van die gemeente te bewaak. "As die gemeente bewaar wil word daarvan om van die weg van navolging af te wyk, dan moet sy uit haar midde ' $n$ groep mense kies, wat in ' $n$ breë kring vertroue geniet en aan hulle opdra om die gemeente te bewaar om draer van die bedoelinge van die Here te bly... Hierdie opdrag is primêr inhoudelik en nie soseer bestuursmatig van aard nie - al moet dit soms as diens van leiding op ' $\mathrm{n}$ bestuursvlak vertaal word' (vry vertaal uit die Nederlands $\mathrm{MN}$ ) In die woorde van Van der Ven "we must go in search of a model that is beyond managerialism, but yet without discarding the positive aspects of this model" (Van der Ven 1998:83).

\subsubsection{Uitsig op totale bediening}

'n Laaste prioriteit ten opsigte van wese (en verbandhoudende roeping, taak of funksie) raak myns insiens die uitsig op die totale bediening van die gemeente waarbinne, van waaruit en ten behoewe van wie hierdie pastorale leiding geskied. Drie sake is hier van belang:

25 Hough \& Cobb (1985:77-94) wy 'n hele hoofstuk aan 'professional church leadership'.

26 Van der Ven (1998:127).Vgl ook Bloth (1981).

27 Heitink (2001:273-274). Vgl die goed gedokumenteerde boek van Shawchuck \& Heuser (1993). 
- hierdie bediening is omvattend of inklusief ten einde bediening te wees;

- hierdie bediening is ekumenies-kontekstueel ten einde Christelik te wees;

- hierdie bediening is missionêr ten einde geloofwaardig (verantwoordbaar) te wees.

Hierdie verstaan gryp terug op die integreringsprinsipe in hierdie navorsing naamlik die identiteit van die gemeente as missionêre gawe van God aan die wêreld. Vir die eise verbonde aan die keuring en uiteindelike kwalifisering vir die 'publieke bediening' onder bespreking is dit belangrik. Dit sluit nie 'gematigde spesialisasie' uit $n^{2}{ }^{28}$. Laasgenoemde blyk almeer ' $n$ noodsaaklikheid te word. Die geheel is nie onoorsigtelik nie, maar die behartiging van al die 'komponente' van die geheel is nie meer moontlik nie. In my vorige artikel het ek so hierna verwys: "Enige roeping tot voltydse bediening in ' $\mathrm{n}$ gemeente het verfyning nodig. Dit gaan om plek vinding, in ooreenstemming met gawes en opleiding, binne die totale bediening. In " $n$ gemeente met slegs een predikant/leraar/pastor is dit natuurlik moeilik. ' $\mathrm{n}$ Kontekstuele verpligting tot alle vorme van bediening verander nog niks aan die beginsel nie. Roeping tot voltydse bediening, ' $n$ roeping tot alle vorme van bediening in die gemeente impliseer nie uitmuntendheid in elke vorm van die bediening nie. Dit impliseer hoogstens verpligting, vanweë die situasie, tot al die vorme van bediening wat deur die situasie vereis word. In die geval waar 'ek' al een is, moet 'ek' byvoorbeeld preek. Dit beteken nog nie dat 'ek' kan preek nie en dat dit my beste bydrae tot die totale bediening is nie" (Nel 2002:154). "n Omskrywing van Buechner wat steeds in kerke se verstaan van roeping en onderskeiding daarvan funksioneer is hier van pas: "The kind of work God usually calls you to is the kind of work (a) you need most to do and (b) that the world most needs to have done... The place God calls you to is the place where your deep gladness and the world's deep hunger meet" ${ }^{29}$. Hoe belangrik hierdie saak in die

28 Heitink (2001:282-285). Heitink vind aansluiting by Van der Ven in sy beskrywings van "general competent" en "special compotent reflection on Ministry” in Van der Ven (1998:160-169).

29 Buechner (1993:118-119). Vgl ook Webster (2002:4) en ook Topp (2003:1). 
beoordeling en onderskeiding van roeping is, word ook beklemtoon in die omvattende studie van Hunt en ander (Dittes 1990:21-26).

Die geheel vra na pastorale leierskap wat kan integreer en koördineer. Die wese van die gemeente as gemeente van Christus in die wêreld vra daarvoor ${ }^{30}$. Net so is dit waar dat die missionêre kontekstualiteit van die gemeente watermerk is vir sy Christelike geloofwaardigheid $^{31}$. Verstaan hiervan as deel van die wese van die 'publieke bediening' is nie belangrik omdat die oorlewing van die kerk daarvan afhang nie. Dit is voorwaarde vir kerkwees. Dit is saam met die ander 'dimensies' van die wese onverhandelbare keuringsprinsipe vir wie kwalifiseer vir die 'offisiële pastorale leierskap'. Myns insiens is dit die teologiese invalshoek om na die pastorale leier as 'visie draer' te verwys. Van der Ven sê tereg dat "the vision of the church concerns its identity" (Van der Ven 1998:100). Wood gebruik die woord 'vision' in sy hoofstuk oor teologiese opleiding (en veral die verband teorie en praxis) om die geheel beeld te beskryf: "a grasp of things in their wholeness and relatedness, a seeing of connections, of how things hang together" (Wood 1985:67).

\section{IN VOORUITSIG}

In die tweede artikel in hierdie reeks word gefokus op die teologiese kern in teologiese opleiding in belang van die sentrale tema van die navorsing naamlik die werwing, keuring en opleiding van voornemende publieke pastorale leiers.

\section{Literatuurverwysings}

Banks, R 1999. Reenvisioning Theological Education. Exploring a Missional Alternative to Current Models. Grand Rapids: Eerdmans.

Barna, G 1998. The Second Coming of the Church. Waco, TX: Word.

Barry, A L 1997. The noble task: A letter to the pastors of the Lutheran Church-Missouri Synod, Vol. 1(1), Lent.

-, 1998. "Challenges in Church and Ministry in the Lutheran Church-Missouri Synod" in Joerz, J C \& McCain, P T (Eds.) Church and Ministry. The Collected Papers of the 150th Anniversary Theological Convocation of the

30 Ek het meer as eenkeer in my werk probeer om ' $n$ saak uit te maak vir hierdie geïntegreerde verstaan van bediening. Vgl Nel (1994); Nel (2002).

31 Omdat dit nie hier die plek is om stellings soos hierdie te beredeneer nie verwys ek slegs na enkele belangrike werke in hierdie verband: Bosch (1982); Guder (ed) (1998); Guder (2000). 
Lutheran Church - Missouri Synod. St. Louis: The Lutheran ChurchMissouri Synod.

Berkhof, H 1973. Christelijk geloof. Een inleiding tot de geloofsleer. Nijkerk: Callenbach.

Bloth, P et al., 1981. Handbuch der Praktischen Theologie. Gütersloh: Gütersloher Verlag.

Böhmer, A C \& Spangenberg, J J 2001. Depressie en angs onder predikante van die Nederduitse Gereformeerde Kerk in Wes- en Suid-Kaap. NGTT 42(1\&2), 6-14.

Bosch, D J 1982. Transforming Mission. Mary Knoll: Orbis.

Brouwer, R 1995. Pastor tussen macht en onmacht. Zoetermeer: Boekencentrum.

Buechner, F 1993. Wishful Thinking. A Seeker's ABC. San Francisco: Harper. (Revised and expanded. First Published 1973.)

Burkat, C S 2003. A Time of Crisis and Opportunity. Congregations 29(1), 3032.

Carroll, J 1985. The Professional model of Ministry - Is it worth saving? Theological Education, 21(2), 7-48.

-, 1986. Ministry as Reflective Practice: a new look at the professional model. Washington, DC: Alban Institute.

Carter, S J 1986. Pastors on the grow: continuing education CAN improve your ministry. St Louis, MO: Concordia Pub. House.

Congar, Yves M J (O.P.) 1967. Lay People in the Church: A Study for a Theology of Laity. (Rev. Ed.) Westminster, Maryland: Newman Press. (Translated by Donald Attwater) Originally published as Jalons pour une théologie du laïcat (Rev. Ed. 1964).

Dawn, M J \& Peterson, E H 2000. The unnecessary Pastor. Rediscovering the Call. (Ed. by Santucci, P) Vancouver: Regent College.

Dingemans, G D J 1986. In de leerschool van het geloof: Mathetiek en vakdidactiek voor catechese en kerkelijk vormingswerk. Kampen: Kok.

Dittes, J E 1990. Tracking God's Call: Basic Theoretical Issues in Clergy Assessment in: Hunt, R A, Hinkle, J E (Jr.) \& Malony, H N (Eds.) 1990. Clergy Assessment and Career Development. Nashville: Abingdon, 21-26.

Dunn, D J G 1992. Jesus' call to discipleship. Cambridge: Cambridge University Press.

Farley, E 1983. Theologia: the Fragmentation and Unity of Theological Education. Philadelphia: Fortress.

Firet, J 1987. 'Zin en betekenis van het ambt' in Firet, J Spreken als een leerling: Praktisch-theologische opstellen. Kampen: Kok.

Gibbs, E 2000. ChurchNext. Quantum changes in how we do ministry. Downers Grove: InterVarsity. 
Gillespie, T W 2004. Why a Theological Education, The Princeton Seminary Bulletin, $X X V(1), 1-11$.

Guder, D L 1998. Missional Church: a vision for the sending of the church in North America. Grand Rapids: Eerdmans.

-, 2000. The Continuing Conversion of the Church. Grand Rapids: Eerdmans.

-, 2002. From mission and theology to missional theology. Inaugural address. Princeton, NJ.: Princeton Theological Seminary.

Heitink, G 2001. Biografie van de Dominee. Baarn: Ten Have.

Hendriks, J 1999. Gemeente als Herberg. De kerk van 2000 - een concrete utopie. Kampen: Kok.

Hofstadter, R 1963. Anti-Intellectualism in American Life. New York: Vintage.

Hoge, D R \& Wenger, J E 2003. Experiences and Attitudes of Protestant Ministers who left local church ministry. Ongepubliseerde 'Preliminary Report', May 12.

Holthaus, S \& Müller, K W (Hg.) 1998. Die Mission der Theologie. F S Hans Kasdorf. Bonn: Verlag für Kultur und Wissenschaft.

Hough, J C \& Cobb, J B 1985. Christian Identity and Theological Education. Chicago,CA.:Scholar Press.

Hunt, R A, Hinkle, J E (Jr.), Malony, H N (Eds.) 1990. Clergy Assessment and Career Development. Nashville: Abingdon.

Johnson, J F 1998. The Office of the Pastoral Ministry:Scriptural and Confessional Considerations in: Joerz, J C \& McCain, P T (Eds.) Church and Ministry. The Collected Papers of the 150th Anniversary Theological Convocation of the Lutheran Church - Missouri Synod. St. Louis: The Lutheran Church-Missouri Synod.

Kalthoff, J 1998. The Pastor: God's Servant for God's People in: Joerz, J C \& McCain, P T (Eds.) Church and Ministry. The Collected Papers of the 150th Anniversary Theological Convocation of the Lutheran Church - Missouri Synod. St. Louis: The Lutheran Church-Missouri Synod.

Kelsey, D H 1992. To Understand God Truly: What's Theolgical About a Theological School. Louisville: Westminster/John Knox.

Kew, R \& White, R 1997. Toward 2015: A church Odyssey. Cambridge, Mass: Cowley.

Lee, P J 1987. Against the Protestant Gnostics. New York: Oxford University Press.

Luther, Martin. 1520. The Freedom of a Christian. AE 31.

Minear, P 1977. Images of the church in the New Testament. Philadelphia: Westminster.

Nel, M 1994. Gemeentebou. Pretoria: Orion, veral Dele $1 \& 2$.

-, 2001. Ek is die verskil. Bloemfontein: CLF. 
-, 2002a. Jeugbediening. 'n Inklusief gemeentelike benadering. Bloemfontein: CLF.

-, 2002b. Predikante Opleiding: Roeping, Keuring en Legitimering. Verbum et Ecclesia 23(1), 151-167.

-, 2004. Who are We? Understanding and finding identity in the local church. Pretoria: CopyMaster.

Niebuhr, H R 1956. The purpose of the Church and its Ministry: Reflections on the Aims of Theological Education. New York: Harper \& Row.

Nouwen, H J M 1977. The living Reminder: service and prayer in memory of Jesus Christ. New York: Seabury.

Perkins, W 1996. The art of prophesying; with The Calling of the Ministry. Edinburgh: Banner of Truth Trust. (First published in Latin 1592, in English 1606).

Presbyterian Outlook. Sept 25, 2000. A Crisis in Leadership: A letter to the Middle Governing Bodies, General Assembly Entities and Theological Institutions of the PC(USA), 10-11.

Rengstorf, K H 1967. Manthanein. Theological Dictionary of the New Testament, 390-461.

Reumann, J H P 1987. Ministries Examined. Laity, Clergy, Women, and Bishops in a Time of Change. Minneapolis: Augsburg.

Ridderbos, H 1973. Paulus: Ontwerp van zijn theologie. Kampen: Kok.

-, 1975. Paul: An outline of his Theology. Grand Rapids: Eerdmans (Vertaal deur J R de Witt).

Roozen, D A, Evans, A F, Evans, R A 1996. Changing the way seminaries teach:globalization and theological education. Hartford, Conn.: Hartford Seminary Center for Social and Religious Research.

Roux, G Wat is die grootste stresfaktore in ' $n$ predikant se lewe? Kruisgewys $1(1), 52-53$.

Schaller, L. 1994. Innovations in ministry. Abingdon: Nashville.

Schawschuck, N \& Heuser, R 1993. Leading the congregation: Caring for yourself while serving others. Nashville: Abingdon.

Schilderman, J B A M, Visscher, C A M, Van der Ven, J A, Felling, A J A 1995. Pastorale Bekwaamheid als kerkelijke survival-strategie. Praktische Theologie 22(2),141-163.

Schippers, K A 1982. Werken aan de gewone gemeente, 1, 2, 3. Praktische Theologie 2, 96-105; Praktische Theologie 3, 181-192; Praktische Theologie 4, 211-224.

Schmidt, K L 1965 Kalein in Kittel, G (ed) Theological Dictionary of the New Testament, 487-535. Grand Rapids: Eerdmans (Vertaal en redigeer deur Bromiley, G W). 
Schner, G P 1993. Education for Ministry. Reform and Renewal in Theological Education. Kansas City: Sheed \& Ward.

Schuth, K 1989. Reason for the hope: The Futures of Roman Catholic Theologates. Wilmington, Delaware: Michael Glazier, Inc.

Sider, R J, Olson, P N, Unruh, H R 2002. Churches that Make a Difference: Reaching your community with good news and good works: Grand Rapids: Baker.

Simmons, P 2003. Supporting Pastoral Excellence, Congregations 29(1), 2930. St. Anselmus: Proslogium, h. 1: in St.Anselm: Proslogium; Monologium; An Appendix in Behalf of the Fool by Gaunilon; and Cur Deus Homo. Vertaal deur Deanne, S N 1958. La Salle, ILL: Open Court Publishing Company.

Stowell, J M 1994. Shepherding the Church into the 21stCentury. Wheaton: Victor Books.

Topp, D M 2003. Pscycological evaluations by Topp Psychological Services. Ongepubliseerde dokument. Holland, MI.

Van der Ven, J A 1998. Education for Reflective Ministry. Leuven (Louvain), Peeters Press.

Van Nijen, J J 1993. Kan ik mijzelf zijn in de gemeente? De predikantsopleiding en de identiteit van de predikant(e). Praktische Theologie 20(1), 43-56.

Walther, C F W 1987. Church and Ministry. Witnesses of the Evangelical Lutheran Church on the question of the Church and Ministry. St. Louis, M O: Concordia. (Vertaling deur Mueller, J T van Walther, C F W 1875. Die Stimme unsere Kirche in der Frage von Kirche und Amt. Erlangen: Andreus Deichert.)

Watson, D L 1981. Discipleship. London: Hodder \& Houghton.

Webster, R M 2002. Considering your call and vocation. PC (U.S.A.) SEIC Resource 92-101.

Wilson, C 1979 ${ }^{4}$. With Christ in the school of Disciple building. Grand Rapids: Zondervan.

Wind, J P \& Rendle, G R 2001. The Leadership Situation facing American Congregations. The Alban Institute. Available online at www.alban.org/ leadership.asp.

-, 2003. Revisiting The Leadership Situation Facing American Congregations, Congregations 29(1), 32-33.

Wood, C M 1985. Vision and Discernment. An Orientation in Theological Study. Atlanta: Scholars Press.

-, 1994. An invitation to Theological Study. Valley Forge, P A: Trinity Press International. 
Woodruff, R L 1993. Towards excellence in Ministerial Education: An Educational Model for Program Development and Improvement. Canberra, Aus.: St. Mark's National Theological Centre.

Working Party on Assessment of the Committee for Theological Education. 1987. Education for the Church'c Ministry. London: Advisory Council for the Church's Ministry. 